\title{
SPONSORING W SEKTORZE KULTURY W POLSCE - BARIERY ROZWOJU
}

\section{Wstęp}

Finansowanie kultury przez podmioty prywatne ma na świecie bardzo długą tradycję. Najstarszą jego formą jest mecenat, który swój początek miał już w czasach starożytnych. Uznawano wówczas, że osoba posiadająca wyższy status społeczny jest zobowiązana do wspierania sztuki i działań artystycznych. Głównym wyróżnikiem mecenatu jest bezinteresowność działania. Darczyńca wspiera sztukę z osobistych pobudek, z zamiłowania do sztuki. Nie oczekuje on w zamian promocji czy reklamy, często chce pozostać anonimowym. W obecnych czasach taki mecenat ma jednak miejsce bardzo rzadko, gdyż uważa się, że każde działanie na rzecz innych ma swoją wartość i dlatego powinno zostać wycenione oraz zrównoważone działaniem wzajemnym ${ }^{1}$.

Stosunkowo nowsze zjawisko sponsoringu oparte jest na dwustronnej umowie pomiędzy podmiotem obdarowującym i obdarowywanym. W przeciwieństwie do mecenasa, sponsor oczekuje, a nawet wymaga pewnych korzyści zwrotnych w kategorii oddziaływania publicznego. Jego interes $\mathrm{w}$ dotowaniu kultury może być bardzo różnorodny i w dużej mierze zależy od przyjętej przez niego strategii. Głównie odnosi się on do promocji, informacji o nowym produkcie czy nowej marce, zwrócenia uwagi mediów. Sponsoring to także możliwość dotarcia do wyselekcjonowanej grupy potencjalnych klientów oraz kreowanie wizerunku firmy, polegające na wywoływaniu pozytywnych skojarzeń z marką firmy odpowiedzialnej społecznie. Ponadto pracodawcy wykorzystują go jako narzędzie motywacji własnych pracowników.

Sponsoring stanowi zatem narzędzie biznesowe w szczególności służące do:

- budowania marki,

- zwiększania rozpoznawalności firmy,

- komunikacji z otoczeniem,

- identyfikacji pracownika z firmą,

- tworzenia oferty socjalnej dla pracowników (karnety na kulturę),

- konstruowania pozytywnych skojarzeń i wizerunku firmy przyjaznej społeczeństwu,

- podniesienia wiarygodności w oczach kontrahentów.

* Doktorantka, Katedra Zarządzania Miastem i Regionem, Wydział Zarządzania UŁ.

${ }^{1}$ A. M. Grzegorczyk, Sponsoring kultury, Oficyna Wydawnicza ASPRA-JR, Warszawa 2003, s. 46. 
Narzędzie to może pełnić bardzo ważną rolę w realizowaniu strategii marketingowej firmy. Wspieranie działalności artystycznej pozwala podmiotom prywatnym zarówno na aktywne uczestnictwo w misji rozwoju i ochrony kultury, jak i na budowę własnego wizerunku jako podmiotu inwestującego w kulturę i czerpiącego korzyści z jej rozwoju².

Kultura w Polsce jest dotowana przede wszystkim ze środków publicznych. Jako główne źródło finansowania swojej działalności organizacje najczęściej traktują fundusze Ministerstwa Kultury i Dziedzictwa Narodowego oraz subwencje samorządowe. Przy malejących dotacjach państwowych, instytucje kultury chcąc rozwijać swoją ofertę i kontynuować działalność, muszą myśleć także o innych źródłach finansowania, w tym także o prywatnych. Okazuje się, że mimo tych przesłanek, tylko nieliczne $\mathrm{z}$ nich skutecznie poszukują możliwości pozyskiwania funduszy $\mathrm{z}$ innych źródeł. To historycznie, bardzo silne, powiązanie $\mathrm{z}$ dotacjami publicznymi oraz brak umiejętności wyjścia naprzeciw zmieniającej się rzeczywistości, implikuje fakt, że średnio najmniejszą liczbę sponsorów pozyskują instytucje państwowe, natomiast najwięcej organizacje pozarządowe, nie mające bezpośredniego dotowania z budżetu państwa.

Poniższy wykres obrazuje udział różnych źródeł finansowania przeznaczonych na działalność instytucji kultury. Środki pochodzące od osób i przedsiębiorstw prywatnych stanowią zaledwie $12 \%$ całego budżetu, najwięlkszą część tworzą finanse publiczne.

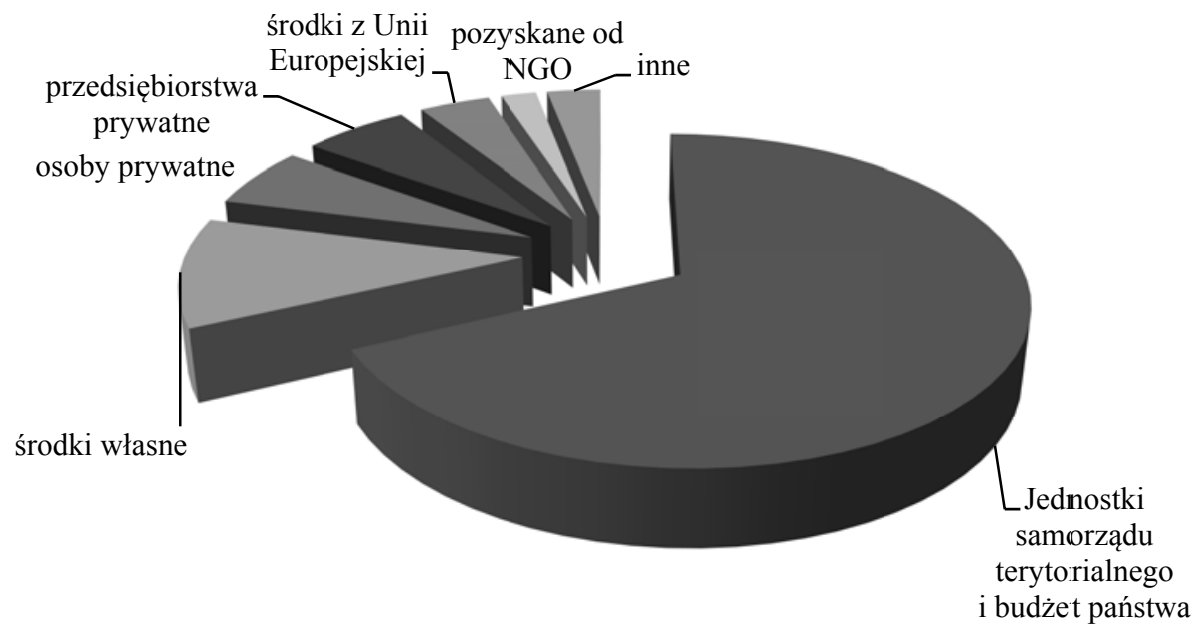

Rysunek 1. Pochodzenie środków na działalność instytucji kultury (w \%)

Źródło: opracowanie własne na podstawie raportu Sponsoring kultury, Raport TNS OBOP, Grudzień 2010, str. 10. Badanie przeprowadzono na próbie 401 instytucji kultury.

${ }^{2}$ Kodeks sponsoringu kultury, Narodowe Centrum Kultury, PKPP Lewiatan, Warszawa 2011, s. 2. 
Przeszkody dla rozwoju prywatnego finansowania działalności artystycznej w Polsce mogą mieć różne podłoże. Inne utrudnienia dostrzegają instytucje kultury, inne potencjalni sponsorzy. Rozważając problem sponsoringu trudno nie zderzyć tych dwóch punktów widzenia. Celem niniejszego opracowania jest próba weryfikacji oraz przeprowadzenie analizy barier i obaw, które stanowią swoisty hamulec rozwoju sponsoringu kultury w Polsce.

\section{Bariery rozwoju sponsoringu w sektorze kultury generowane przez instytucje kultury}

W Stanach Zjednoczonych, a także w niektórych krajach Europy Zachodniej działalność sponsorska zyskała wysoki stopień akceptacji społecznej i dzisiaj jest powszechnie stosowana. Właśnie akceptacja sponsoringu i jego powszechność otwierają przed tym instrumentem promocji szerokie perspektywy, które umożliwiają wspieranie kultury różnych krajów na finansowaniu prywatnym. Jednakże przed działaniami sponsoringowymi stoją przeszkody, które mogą ograniczyć efekty tego typu zaangażowania firm, a co za tym idzie zniechęcić przedsiębiorstwa do stosowania tego instrumentu promocji ${ }^{3}$.

Cechą charakterystyczną instytucji kultury w Polsce jest ich silne uzależnienie od środków publicznych. Przekłada się to na brak aktywności w pozyskiwaniu sponsorów. W 70\%, badanych instytucji pozyskiwaniem dodatkowych środków na finansowanie działalności bieżącej i projektowej, zajmuje się osoba, która ma inne stanowisko, a szukanie źródeł finansowania stanowi dla niej dodatkowe zajęcie. W $20 \%$ przypadków jest to przypadkowa osoba, a tylko w $10 \%$ osoba specjalnie zatrudniona do tego celu ${ }^{4}$. Trudno spodziewać się, że $\mathrm{w}$ ten sposób funkcjonujące instytucje będą odnosić sukces w znajdywaniu partnerstwa do realizacji swoich projektów. Pozyskiwanie środków pozabudżetowych nie może mieć charakteru doraźnego i zaradczego, lecz musi być wpisane $\mathrm{w}$ długoterminową politykę instytucji. Potencjalny sponsor potrzebuje czasu, aby podjąć odpowiednią decyzję, zaplanować wydatki i wdrożyć strategię marketingową. Oferty współpracy są często przygotowywane tuż przed mającym nastąpić wydarzeniem kulturalnym, co uniemożliwia przedsiębiorstwom, o bardziej skomplikowanej strukturze decyzyjnej, przystąpienie do projektu. Należy pamiętać, że inwestycja w kulturę ma charakter długoterminowy. Utożsamianie i kreowanie marki trwa kilka lub nawet kilkadziesiąt lat, dlatego współpraca pomiędzy sztuką a biznesem musi zakładać szerszy zakres czasowy i być odpowiednio wcześniej przygotowana.

${ }^{3}$ M. Datko, Sponsoring. Klucz nowoczesnego marketingu, Wydawnictwo Placet, Warszawa 2012, s. 473.

${ }^{4}$ Raport z badania Kultura do finansowania, Ministerstwo Kultury i Dziedzictwa Narodowego, Warszawa 2012, s. 6. 
Drugą, bardzo istotną kwestią jest postrzeganie sponsoringu przez same instytucje kultury. Pomimo, że deklarują one, iż nie posiadają wystarczających środków na prowadzenie i rozszerzanie swojej działalności, to wciąż opornie odnoszą się do współpracy z partnerem biznesowym. Wynika to, z jednej strony, $\mathrm{z}$ niechęci do bycia identyfikowanym ze sponsorem, $\mathrm{z}$ drugiej natomiast ze strachu przed współpracą i utożsamieniem z przedsiębiorcą. Instytucje kultury wyrażają obawę przed wpływem na ich niezależność programową. W Polsce wciąż panuje stereotyp, że sponsoring doprowadza do utraty autonomiczności przez kulturę. Ponadto, w przeciwieństwie do krajów wysoko rozwiniętych, nie istnieje jeszcze powszechna społeczna akceptacja tego rodzaju finansowania. Sponsor bywa sprawą wstydliwą, jego logo jest niewielkie ${ }^{5}$. Wśród instytucji kultury występuje niechęć do oferowania darczyńcom atrakcyjnych dla nich świadczeń, w tym informowania o nich $\mathrm{w}$ mediach $^{6}$. Powyższe obawy i stereotypy łączą się z dyskusją na temat wpływu sponsoringu na komercjalizację kultury i często nieuzasadnioną społeczną dezaprobatą sponsoringu $\mathrm{w}$ sferze kultury wysokiej. Wydaje się jednak, że w przypadku prawidłowo dobranych celów zarówno instytucji kultury, jak i darczyńcy sponsoring nie musi oznaczać komercjalizacji sztuki. Co więcej, świadomy sponsor nie będzie dążył do tego rodzaju ograniczania twórczości, gdyż mogłoby to negatywnie wpłynąć na kreowany przez niego wizerunek.

Jednym z głównych zarzutów wobec instytucji kultury jest nieumiejętność przygotowania atrakcyjnej i kompleksowej oferty, która mogłaby zostać przedstawiona potencjalnemu sponsorowi. W dzisiejszych czasach nie wystarczy już tylko dobry koncept, to musi być projekt skierowany do konkretnego partnera, uwzględniający jego specyficzne potrzeby. Wśród artystów istnieje problem braku wiedzy na temat skonstruowania prawidłowej, konkretnej i zachęcającej oferty sponsorskiej. Niska świadomość tego, co można zaoferować sponsorowi, sprawia, że przedstawiane propozycje są zwyczajnie nieatrakcyjne dla kontrahentów. Instytucje kultury nie prowadzą analizy oczekiwań partnera, nie identyfikują jego potencjalnych odbiorców jako grupy docelowej kampanii sponsorskiej. Oferty są składane bez uprzednio przeprowadzonych badań rynkowych, co już na początku skazuje je na niepowodzenie. Sektorowi kultury brakuje profesjonalizmu, którego w dzisiejszych czasach wymagają partnerzy biznesowi, zarówno pod względem wzajemnej współpracy, jak i organizacji dotowanego wydarzenia.

${ }^{5}$ Więcej biznesu w kulturze - wywiad z Ewą Łabno-Falęcką, https://businessandculture. wordpress.com/2013/01/01/wiecej-biznesu-w-kulturze-wywiad-z-ewa-labno-falecka/ (dostęp 01.01.2013).

6 J. Polakowska-Kujawa, Sponsoring Kultury- wybrane problemy, [w:] A. Grzegorczyk (red.), Sponsoring kultury, Wyższa Szkoła Promocji w Warszawie, Warszawa 2004, s. 6. 
Często występującym zjawiskiem jest ograniczanie się organizacji do współpracy tylko z jednym, kluczowym sponsorem, mogącym sprostać finansowaniu całego wydarzenia. Jednocześnie rezygnuje się z małych i średnich przedsiębiorstw, które również mogłyby stać się darczyńcą pod warunkiem, iż skierowana do nich oferta będzie dopasowana do ich potrzeb i skrojona na miarę możliwości. Sponsor powinien być starannie wyselekcjonowany spośród wszystkich podmiotów uczestniczących w rynku, a propozycja współpracy zaadresowana do konkretnego podmiotu. Tylko znajomość potrzeb sponsora pozwoli na sporządzenie atrakcyjnej i trafionej oferty.

Rysunek 2 przedstawia wyniki badania, w którym instytucje kultury identyfikowały bariery w pozyskiwaniu sponsora. Najwięcej organizacji wykazuje brak zainteresowania ze strony podmiotów prywatnych oraz fakt, że nigdy mie przygotowywały oferty sponsorskiej. Podobna jest ocena przedsiębiorców, którzy jako główny powód niedotowania kultury również wymieniają brak otrzymywania ofert sponsorskich. Niepokojący jest fakt, iż pomimo zbyt niskiego finansowania wiele organizacji w ogóle nie ubiega się o wsparcie do sektora prywatnego.

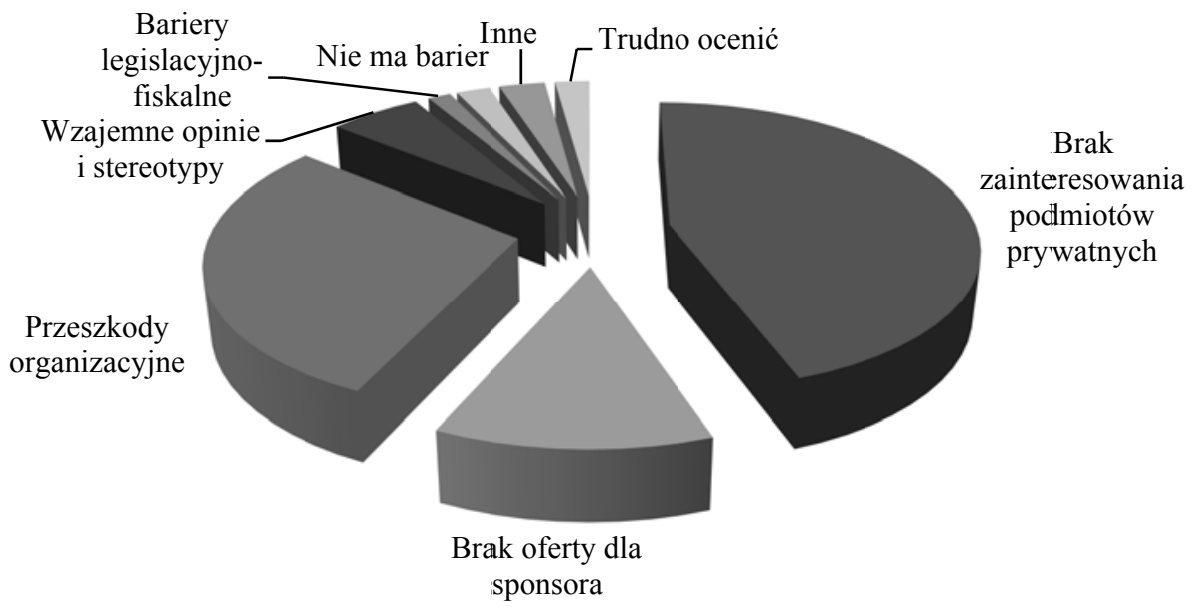

Rysunek 2. Bariery w pozyskiwaniu sponsora w ocenie instytucji kultury (w \%)

Źródło: opracowanie własne na podstawie raportu Sponsoring kultury, Raport 'TNS OBOP, Grudzień 2010, s. 26. Badanie przeprowadzono na próbie 401 instytucji kultury.

Instytucje kultury wskazują na przeszkody organizacyjne, które utrudniają ich współpracę z biznesem. Wśród nich występują problemy ze znalezieniem odpowiedniej formy prawnej dla planowanej kooperacji, niemożliwość dostosowania budżetów instytucji sponsorującej i sponsorowanej a także niejasne zasady podejmowania decyzji przez podmioty prywatne ${ }^{7}$. Wydaje się jednak, że

${ }^{7}$ M. Openchowska, W. Zakrzewska, Sponsoring kultury, Raport TNS OBOP z badania instytucji kultury, Narodowe Centrum Kultury, Grudzień 2010, s. 29. 
przeszkody organizacyjne występują znacznie częściej po stronie organizatora działań artystycznych. Cechą charakterystyczną instytucji o statusie podmiotu publicznego jest kadencyjność i wybieralność władz, co powoduje, iż działania nie są planowane długoterminowo i mają charakter doraźny. Sponsor nie może mieć pewności, czy polityka firmy będzie kontynuowana po zmianie menadżera. Ponadto istotną kwestią jest także fakt, iż instytucje wykazują się małą elastycznością oraz problem $z$ podejmowaniem szybkich i wiążących decyzji przez menadżerów kultury. Duża biurokracja panująca w sektorze państwowym to kolejny czynnik zniechęcając do zawierania partnerstw pomiędzy publiczno-prywatnych.

Sponsoring wydaje się być dobrą alternatywą dla finansowania kultury i większość instytucji dostrzega jego zalety. Ten typ finansowania jest postrzegany jednak głównie jako uzupełniający inne źródła. Tylko $2 \%$ instytucji uważa, że podobnie jak w Stanach Zjednoczonych, środki prywatne powinny pełnić kluczową rolę i stanowić najważniejszą część budżetu. Znacznie częstszą jest opinia, że sponsoring powinien odgrywać jak najmniejszą rolę wśród dostępnych źródeł finansowania. Postrzeganie sponsorów przez instytucje kultury prezentuje poniższy wykres.

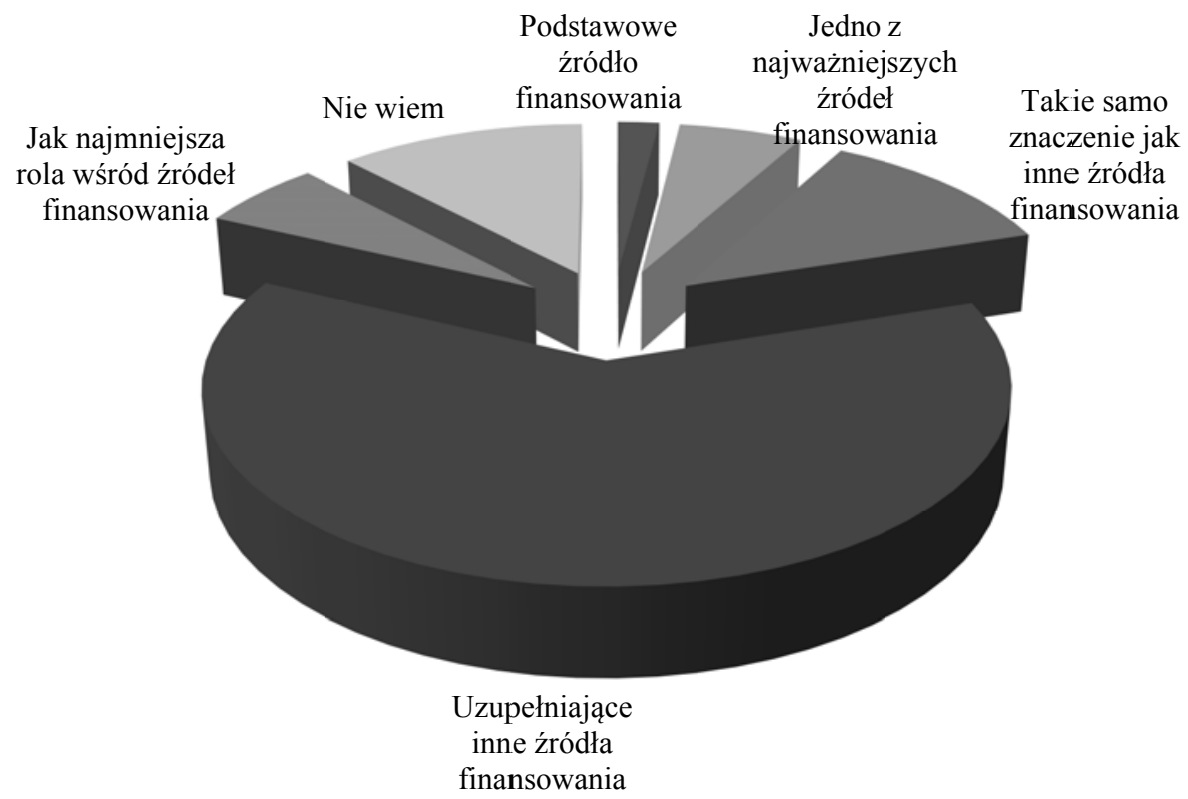

Rysunek 3. Rola środków finansowych pozyskanych ze źródeł prywatnych (w \%)

Źródło: opracowanie własne na podstawie raportu Sponsoring kultury, Raport TNS OBOP, Grudzień 2010, s. 23. Badanie przeprowadzono na próbie 401 instytucji kultury. 


\section{Bariery rozwoju sponsoringu w sektorze kultury generowane przez sferę biznesu 10}

Do podstawowych barier rozwoju sponsoringu w Polsce należy zaliczyć sytuację ekonomiczną przedsiębiorstw. Uwarunkowania gospodarcze i finansowe wywierają znaczny wpływ na politykę firm w zakresie podejmowanych działań marketingowych. W czasie kryzysu pierwszymi wydatkami ograniczanymi przez firmy są koszty promocji, w tym także sponsoringu. Stąd pierwszą przeszkodą rozwoju sponsoringu wykazywaną ze strony biznesu jest właśnie brak środków na taką działalność.

Często podnoszona jest kwestia braku zainteresowania sfery biznesu wspieraniem sztuki. Taki stan rzeczy może mieć kilka przyczyn. Po pierwsze, wśród przedsiębiorców występuje niska świadomość korzyści, jakie można odnieść ze sponsoringu kultury. Polski biznes nie ma długich doświadczeń w kreowaniu marki za pomocą tego narzędzia. Utożsamiane jest ono często jedynie z wykupieniem reklamy na banerze reklamowym imprezy kulturalnej. Podobnie jak w przypadku instytucji kultury, występuję tu problem braku wiedzy i profesjonalizmu w tej dziedzinie.

Firmy z kapitałem zagranicznym lub zarządzane przez obcokrajowców potrafią dużo lepiej wykorzystać profity płynące ze współpracy z kulturą i odnieść sukces. Często wiążą się z wybraną instytucją na długie lata i czerpią z tego ogromne korzyści. Polskie firmy nadal oczekują szybkiego zwrotu z inwestycji i niemal natychmiastowych niemal efektów. Decyzje o sponsoringu są podejmowane impulsywnie, bez gruntownego przemyślenia i strategii marketingowej. Przedsiębiorcy skarżą się na brak informacji na temat możliwości współpracy z kulturą, jednocześnie sami nie potrafią dokonać analizy potrzeb i wybrać właściwego partnera. To wszystko spowodowało, iż w pierwszym okresie popularyzacji sponsoringu wiele inwestycji w działalność artystyczną okazało się bezskutecznych.

Kolejną przyczyną braku podejmowania inicjatywy przez przedsiębiorców w obszarze kultury jest zwrócenie się ku sponsoringowi w innych dziedzinach. W Polsce nadal najpopularniejsze jest wspieranie sportu i wydarzeń $z$ nim związanych. Korzyści z dotowania tego rodzaju imprez upatruje się w dużej ilości ludzi na widowni, a tym samym wielu odbiorcach zamieszczonej reklamy. Wchodząc w partnerstwo z kulturą firma powinna upatrywać innego zysku. Nie chodzi tu bowiem o reklamę masową, dla której rzeczywiście lepszym miejscem okaże się boisko piłkarskie, ale o zbliżenie stron w kreatywnym procesie marketingowym, które znaczy dla organizacji więcej niż logo, obok którego odbiorca przechodzi coraz bardziej obojętnie ${ }^{8}$.

${ }^{8}$ K. Lewandowska, Sponsoring kultury - kto komu pomaga?, www.kulturasieliczy.pl. (dostęp 02.01.2013). 
Poza determinantami ekonomicznymi na wybór kultury, jako dziedziny sponsorowanej, mają wpływ w dużej mierze upodobania właścicieli podmiotów prywatnych. Dyrektorzy firm, którzy decydują o dystrybucji środków, nie rozumieją kultury. Niska edukacja w tym zakresie, do której w Polsce przez dłuższy czas nie przywiązywano uwagi, zbiera obecnie swoje żniwo w postaci braku zainteresowania tą dziedziną. Tymczasem szereg firm dokonuje wyboru podmiotu sponsorowanego bazując właśnie na sympatiach i gustach właścicieli.

\section{Bariery legislacyjne}

Oprócz barier leżących po stronie kultury i biznesu istnieje szereg przeszkód legislacyjnych utrudniających zawieranie partnerstw mających na celu dotowanie sztuki ze źródeł prywatnych.

W Polsce umowa sponsorska rozliczana jest jako zwykła usługa kupnasprzedaży, na którą należy wystawić fakturę VAT. Jest to czynnik, który w dużej mierze zniechęca do takiej formy dotowania kultury. Sposobem na ominięcie zobowiązań podatkowych może być umowa barterowa, która określa bezgotówkową, ekwiwalentną wymianę dóbr czy usług. Takie podejście do sprawy uniemożliwia jednak przekazanie instytucji kultury pomocy w formie gotówki. Ponadto problem z umowami barterowymi może pojawić się dla instytucji kultury w przypadku bardziej skomplikowanego montażu finansowego łączącego środki publiczne i prywatne. Niektóre publiczne programy dotacyjne nie uznają bowiem barteru jako możliwego finansowego wkładu własnego w realizację zadania, a jedynie jako wkład rzeczowy.

Kolejnym utrudnieniem legislacyjnym jest brak możliwości odliczenia od podatku darowizny dla przedsiębiorców rozliczających się na zasadach podatku liniowego oraz karty podatkowej. Tymczasem w niektórych krajach europejskich próbuje się likwidować tego rodzaju ograniczenia, a partnerstwo kultury z biznesem jest premiowane. W Polsce brak jest programów rządowych mających na celu wspieranie tego rodzaju współpracy. Taka postawa państwa często jest wytykana przez podmioty ze środowiska biznesowego $\mathrm{w}$ dyskusji na temat sponsoringu.

Przepisy legislacyjne mają także wpływ na branżę, która decyduje się na wspomaganie sztuki. Według badań TNS OBOP instytucje kultury sponsorowane były przede wszystkim przez firmy z branżं: energetycznej, gazowniczej, usług hotelarskich, produkcji, mediów, bankowości i finansów. Zakaz związany z reklamą niektórych produktów, jak na przykład wyrobów tytoniowych czy alkoholowych, niemalże uniemożliwia ich producentom korzystanie $\mathrm{z}$ dobrodziejstw sponsoringu.

Pojęcia sponsoringu i kultury są ściśle powiązane z mediami, gdyż to dzięki nim informacja o organizowanej działalności artystycznej jest rozpowszechnia-

\footnotetext{
${ }^{9}$ M. Openchowska, W. Zakrzewska, Sponsoring..., s. 16.
} 
na. W interesie sponsora leży, aby jego marka była obecna w masmediach. Polskie środowiska medialne unikają mówienia o donatorach. Jedną, aczkolwiek na pewno nie jedyną, przyczyną takiego stanu rzeczy jest ustawa zakazująca kryptoreklamy. Warto wspomnieć, że przedstawianie i promowanie sponsorów w mediach ma także dodatkowy pozytywny efekt, gdyż przyczynia się do propagowania postawy odpowiedzialności społecznej wśród przedsiębiorców.

Zarówno podmioty sponsorujące jak i sponsorowane napotykają poważne bariery legislacyjne, które dotkliwie ograniczają potencjalną współpracę kultury $\mathrm{z}$ biznesem. Państwo nie promuje tego typu kooperacji, nie ułatwia zawiązywania partnerstw, w końcu nie tworzy przepisów, dzięki którym sponsoring byłby bardziej korzystny dla obydwu stron. Nie dostrzegany jest potencjał sponsoringu, który w przyszłości mógłby przynieść wymierne rezultaty dla Skarbu Państwa, przenosząc część ciężaru finansowania kultury w stronę środków prywatnych.

\section{Zakończenie}

Sponsoring kultury i sztuki wymaga długofalowej i równoważnej współpracy dwóch stron. Jego podstawowym założeniem jest świadczenie usług wzajemnych na ustalonym gruncie. Wymaga on przemyślanej i dopracowanej koncepcji, a także równego zaangażowania obydwu partnerów, o czym zdają się nie pamiętać ani przedsiębiorcy ani podmioty kultury. Sztuka i biznes, podobnie jak nauka i biznes, mogą i powinny się wzajemnie przenikać, gdyż mają sobie bardzo dużo do zaoferowania $i$ to nie tylko pod względem finansowym, ale także doradczym. Wykorzystanie potencjału kultury $\mathrm{w}$ obrębie wpływu na rozwój organizacji poprzez, m.in. stymulowanie procesów kreatywnych, poprawę komunikacji i relacji, budzenie ducha pracy grupowej ${ }^{10}$ powinno być kluczowe dla przedsiębiorcy.

Profity ze sponsoringu dla obydwu stron mogą być znaczące. Trzeba jednak pamiętać, że wynikające z niego ryzyko także ponoszą obydwie strony kontraktu. Największe zagrożenie dla sponsora wynika z obrania złej strategii marketingowej związanej z dotowaniem kultury. Ważne jest posiadanie dobrego rozeznania wśród oferty kulturalnej i wyłonienie właściwej dziedziny, spójnej z wizerunkiem firmy. Kolejną barierą dla przedsiębiorców jest oczekiwanie szybkiego zwrotu wyłożonego kapitału. Inwestycja w kulturę polegająca na kreowaniu marki ma jednak charakter długoterminowy i w związku z tym niezbędna jest cierpliwość i konsekwencja w podejmowanych działaniach. Jak wykazują badania, zwrot z dotowania działań artystycznych może być bardzo wysoki, a osiągnięty efekt marketingowy trwały i odporny na wahania koniunktury.

Powszechna jest opinia o zbyt niskim finansowaniu kultury i braku zainteresowania tym obszarem ze strony biznesu. W sytuacji, gdy prawie $80 \%$ instytucji kultury deklaruje chęć pozyskania sponsora, dziwnym wydaje się fakt, że

\footnotetext{
${ }^{10}$ K. Lewandowska, Sponsoring...
} 
instytucje te nie uważają pozyskanie sponsora za istotną część swojej działalności. Warto zatem poddać refleksji, czy hasło „komercjalizacja kultury” nie stanowi jedynie wymówki ukrywającej brak kompetencji i umiejętności pozyskania finansowania prywatnego. Bezsprzeczny jest bowiem fakt, że aktywne szukanie sponsora, wymaga wiedzy i umiejętności, a instytucje kultury nie są do tego przygotowane.

Finansowanie kultury ze środków prywatnych wymaga przełamania pewnej sztucznej bariery współpracy kultury, i to tej najbardziej elitarnej, z biznesem. Przy odpowiednim zaangażowaniu każdego z partnerów możliwe jest doprowadzenie do sytuacji win-win, w której obydwie strony są wygrane i odnoszą korzyści ze współpracy.

\section{Literatura}

Datko M., Sponsoring. Klucz nowoczesnego marketingu, Wydawnictwo Placet, Warszawa 2012. Grzegorczyk A., Sponsoring kultury, Oficyna Wydawnicza ASPRA-JR, Warszawa 2003.

Kodeks sponsoringu kultury Narodowe Centrum Kultury, PKPP Lewiatan, Warszawa 2011.

Lewandowska K., Sponsoring kultury - kto komu pomaga?, www.kulturasieliczy.pl.

Openchowska M., Zakrzewska W., Sponsoring kultury, Raport TNS OBOP z badania instytucji kultury, Narodowe Centrum Kultury, Grudzień, 2010.

Polakowska-Kujawa J., Sponsoring kultury - wybrane problemy, [w:] A. Grzegorczyk (red.), Sponsoring kultury, Wyższa Szkoła Promocji w Warszawie, Warszawa 2004.

Raport z badania, Kultura dofinansowania, Ministerstwo Kultury i Dziedzictwa Narodowego, Organizator badania Punkt Kontaktowy ds. Kultury, Warszawa 2012.

Sieczkowski W., Społeczne znaczenie sponsoringu kultury, [w:] A. Grzegorczyk (red), Sponsoring Kultury, Wyższa Szkoła Promocji w Warszawie, Warszawa 2004.

Więcej biznesu w kulturze - wywiad z Ewą Labno-Falęcką, https://businessandculture.wordpress. com/2013/01/01/wiecej-biznesu-w-kulturze-wywiad-z-ewa-labno-falecka/

\section{Streszczenie}

Środki prywatne to wciąż najmniej popularne źródło finansowania kultury w Polsce. Rozwój sponsoringu napotyka wiele przeszkód zarówno od strony instytucji kultury jak i przedsiębiorcy. Celem niniejszego opracowania jest próba weryfikacji oraz przeprowadzenie analizy barier i obaw, które stanowią swoisty hamulec rozwoju sponsoringu kultury w Polsce.

\section{Summary}

\section{SPONSORSHIP IN THE CULTURE IN POLAND- BARRIERS TO DEVELOPMENT}

Private funds are still the least popular source of funding for culture in Poland. Development of sponsorship, it faces many barriers both from cultural institutions and businesses. The purpose of this paper is to review and analyze the barriers and concerns which are specific brake on the development of sponsorship culture in Poland. 